\title{
Greening of higher education in the Republic of Serbia
}

Vesna Nikolić, Slobodan Milutinović, Jelena Ranitović

Envigogika 10 (2) - Reviewed Papers/ Recenzované články

Published/ Publikováno 23. 1. 2015

DOI : $\underline{10.14712 / 18023061.453}$

\begin{abstract}
Numerous environmental protection issues and problems in the Republic of Serbia have forced the authors of this paper to devote their attention to research and analyse the current state of higher education for environmental protection within the Serbian educational context. More precisely, it is a continuation of the study entitled "Rethinking higher education for sustainable development in Serbia" (Milutinović and Nikolić, 2014), which was completed by the authors of this paper on the basis of the assessment of Copernicus Charter principles in higher education in the Republic of Serbia. In this paper, the results of the assessment of environmental programmes in current higher education practices are shown, and they were created within the project called University Educators for Sustainable Development - UE4SD, Lifelong Learning Programme, Erasmus Programme. The first part of the paper clarifies the need for and importance of greening higher education in the light of sustainable development concepts and strategies. The country context and regulatory frameworks of higher education and education for sustainable development in the Republic of Serbia are presented in the second part of the paper. The third part of the paper shows results of the analysis of Serbian higher education programmes in environmental protection, with a special emphasis on programmes for training future experts for environmental protection and the state of greening higher education in our country. In this regard, an analysis of present ecological ideas and content in the syllabus of the English language, which is one of the most common courses at Serbian faculties, and which is particularly important in response to the challenges of globalisation, knowledge flow, international scientific research and mobility, is performed. Finally, as part of the authors' concluding remarks, improvements related to the period before the reform of higher education and adoption of the National Strategy for Sustainable Development (NSDS) are presented. New directions of the education for environmental protection in higher education, as well as the importance of educating educators for sustainable development, are shown.
\end{abstract}

\section{Key words:}

sustainable development, environmental protection, greening, higher education

\begin{abstract}
Abstrakt:
Četné environmentální problémy Srbska přispěly $\mathrm{k}$ tomu, že autoři tohoto textu věnovali pozornost výzkumu a analýze současného stavu vysokoškolského vzdělávání v oblasti ochrany prostředí na srbských vysokých školách. Přesněji jde zde o pokračování studie s názvem "Nový pohled na vysokoškolské vzdělávání pro udržitelný rozvoj v Srbsku“
\end{abstract}


(Milutinović, Nikolić, 2014), kde autoři tohoto článku hodnotili uplatnění principů Charty COPERNICUS ve vysokých školách $v$ Republice srbské. $V$ tomto článku se programy vysokých škol hodnotí podobně, jak bylo činěno $v$ mezinárodním projektu University Educators for Sustainable Development - UE4SD. V první části textu se ujasňuje význam změny vysokého školství směrem ke konceptům a strategiím udržitelného rozvoje. Politické podmínky vysokoškolského vzdělávání a předpoklady vzdělávání pro udržitelný rozvoj $v$ Republice srbské jsou rekapitulovány $v$ druhé části textu. Ve třetí části jsou ukázány výsledky analýzy srbských vysokoškolských programů v oblasti ochrany prostředí, se zvláštním důrazem na vzdělávání budoucích expertů a stav transformace vysokoškolského systému směrem $\mathrm{k}$ udržitelnosti. $\mathrm{Z}$ tohoto hlediska byla provedena analýza současného ekologického myšlení a témat $v$ sylabech anglického jazyka, což je na srbských vysokých školách jeden z nejčastějších kurzů, který je současně velmi významný z hlediska globalizačních trendů, informačních toků, mezinárodního vědeckého výzkumu a mobility. Nakonec, jakožto závěrečné poznámky, jsou ukázány změny, které se vztahují k období před transformací vysokoškolského systému a souvisejí s přijetím Národní strategie pro udržitelný rozvoj. Článek je zakončen přehledem nových směrů ve vzdělávání k ochraně prostředí na vysokoškolské úrovni a zdůrazněním významu vzdělávání vysokoškolských učitelů v této oblasti.

\section{Klíčová slova:}

udržitelný rozvoj, ochrana prostředí, ozelenění, vysoké školství 


\section{I ntroduction}

Unfortunately, current developments in different parts of the world show that climate change and environmental degradation are of huge proportions so that emergencies and natural disasters have become part of everyday life of modern people. Moreover, degradation and depletion of natural resources exacerbate economic and social problems, and will open many questions related to sustainable development in the future.

Nowadays, Serbia is not at a satisfactory level of sustainability due to the well-known events that occurred within the past two decades. According to the European Commission, environmental protection is an area in which Serbia will have to exert its maximum effort to fully meet European standards and the requirements of sustainable development in the future (Serbia 2013 Progress Report, European Commission, 2013). Poor water quality in some parts of the country, undeveloped systems of waste collection and recycling, illegal dumps, and industrial pollution are some of the environmental problems affecting the Republic of Serbia. These findings have encouraged the authors of the paper to focus on the environmental problems, more precisely on environmental protection problems as a dimension of education for sustainable development in Serbian higher education.

Environmental protection, as a dimension of sustainable development, attracts the attention of the scientific community. Scoullos (1995) notes that "the idea of environmental protection was never cut off from the idea or the need for a particular type of development". Environmental challenges have brought education to the epicentre of national strategies for the protection of the environment, sustainable economy, and secure future (Sauvé, 1996; Potter, 2010; Marcinkowski, 2014). Increasing public awareness and knowledge on environmental issues, development of skills, attitudes, values, critical thinking, and ability to make informed decisions on environment, and in order to take responsible actions, are exactly the goals that education about/in/for the environment should bring (Tilbury, 1997).

Even after the 1992 United Nations Conference on Environment and Development (UNCED, 1992), certain tensions between the concepts of more established Environment Education (EE) and the newer Education for Sustainable Development (ESD) over matters of definition, scope, need, purpose, and prospects can be found in literature (Sato, 2006; Vare and Scott, 2007). Threats and challenges of the modern era imply mutual connection and interdependence of environmental protection and sustainable development and, therefore, imply a holistic approach to education in this area (Dlouhá, 2007; Corcoran and Wals, 2004).

\section{Background}

Recommendations and declarations of a series of international conferences and United Nations strategic planning documents indicate that education is a prerequisite for achieving sustainable development (UN, 1992; Agenda 21; UNECE, 2009; UNECE, 2011; Rio+20, 2012; UNECE, 2013). It also presents an essential tool (McKeown, 2002) in developing competencies and abilities to manage risks, as well as to respond to the challenges of the modern era (UNECE, 2011; UNECE, 2013).

The incorporation of ecological issues into higher education plays an important role in the evolution of society towards sustainability. Education for environmental protection and sustainable criteria should ensure that students join professional activities within the field of environmental protection and sustainable development in the future (Dlouhá and Dlouhý, 2014). The main goal of education for sustainable development should be accepted by all 
universities and it involves forming of opinions, views, and behavioural patterns that will enable versatile, valuable, and effective considerations of ecological ideas, laws, and postulates of sustainable development in students' professional activities (Tilbury, 2004).

Despite the enriched funds of knowledge on environmental problems, it is hard to resist the impression that there is still an evident lack of a holistic, systematic approach to education in this area, which includes professional students' training in the field of environmental protection, as well as greening of the entire system of education. The approach also requires tighter integration of environmental protection content with other sustainable development issues and concerns (Dlouhá, 2007; Marcinkowski, 2010).

Greening is described and defined as an important direction of development of educational systems (Dlouhá and Dlouhý, 2014). In Russian literature, authors use the phrase "ecologised" educational systems (Kozlova and Glazačev, 1998; Logunov et al., 1998) to indicate the idea, the spirit, the new paradigm of modern systems and the process of education in general, which should lead to the process of a society's recovery, and also lead towards creation of moral and inspired people, active, responsible and competent in protecting the environment.

Greening tends to introduce ecological ideas, concepts, principles, ecological approaches from other disciplines, within curricular and extracurricular activities at all levels and in all forms of educational work.

The implementation of ecological issues and problems related to the protection of the environment in higher education curricula, which is understood as an orientation towards sustainability in different study programmes at universities, is regarded as an important element of quality. It also indicates the necessary level of commitment to provide graduate students with advanced and modern knowledge, new competences and skills that will contribute to sustainable development.

In the Republic of Serbia, many universities have accredited their study programmes of academic and professional education in the field of environmental protection and other study programmes related to the environment. Nevertheless, it is still a long way to go in order to establish parameters that will allow a holistic approach to environmental education, taking into account planetary sustainability as part of an integrated approach to knowledge for sustainable development in the future.

\section{Research methodology}

The purpose of this paper is to present the current state in higher education for environmental protection in Serbia. Given that the higher education system in Serbia has undergone a series of changes during the last few years (university reforms, a new legislative framework, signing of the Bologna Declaration, accreditation of new study programmes, etc.), we were interested, firstly, in the compatibility of the legal and strategic framework for higher education with the principles of sustainable development; secondly, how many higher education institutions in Serbia have accredited their study programmes in educating experts/specialists in environmental disciplines and which educational profiles have been introduced, and, finally, which higher education institutions have greened their curricula in terms of implementation of contents related to environmental protection. We have also tried to identify the main obstacles to this process in the Serbian higher education space. 
As a basic criterion for assessing the current state, programmes in environmental education have been observed. This criterion is actually based on one of the principles of the COPERNICUS University Charter for Sustainable Development (The University Charter for Sustainable Development, Geneva, COPERNICUS, 1994) and the fact that three Serbian universities were signatories to the Charter. In this regard, this paper is actually a continuation of the research evaluation of higher education in Serbia (Milutinović and Nikolić, 2014) with a focus on programmes and contents of education for environmental protection in Serbian higher education.

A descriptive research method, with different data collection techniques, was used in this study. In order to process data and interpret the results, a comparative analysis of results was used from interviews along with the published literature and official documents.

Information on higher education institutions and their programmes of study, accredited by the Commission for Accreditation and Quality Assessment (CAQA), is used in the research. An accreditation meeting was held on 9 April 2014, and it included the results of the re-accreditation of colleges of applied sciences conducted during 2013. It also included information about institutions and study programmes accredited by the National Council for Higher Education (NCHE) within their respective jurisdictions, and included on the list that has been submitted to the CAQA by the NCHE.

\section{Findings and results}

\subsection{Country context and legal framework of higher education}

Serbia today is facing a number of economic, demographic, and other transitional challenges and problems. The current economic and financial crisis slows down the economy, puts poverty reduction at risk, and affects employment and environmental problems in Serbia. The crisis may increase poverty most in those parts of the country where a significant proportion of the population lives just above the poverty line, as well as social exclusion. The situation in the field of environmental protection, especially in areas such as waste management, nature protection, air and water quality, is not satisfactory either (Serbia 2013 Progress Report, European Commission, 2013). With regard to higher education, according to official statistics, less than $10 \%$ of the citizens are college-educated and only $14 \%$ holds a higher education degree. Educational deficiency is mostly reflected among the low-income population, and it remains one of the causes of transgenerational transfer of poverty (Vukasović, 2007).

Education in Serbia faces numerous developmental challenges - scientific, humanistic, social, and economic; along with technological innovation, globalisation, and mobility. In response to the challenges of the modern era, the Serbian Government has initiated a reform process of the entire education system, including the higher education system, primarily through legislation. To understand the role of higher education institutions for sustainable development, the following are of great importance:

(1) the national sustainable development initiative, including the NSDS and the Serbia 2020 Strategy, and

(2) the higher education reform based on the Bologna process.

The higher education is regulated by the Higher Education Act (Official Gazette of the Republic of Serbia, no. 76/2005, 100/2007 - authentic interpretation, 97/2008, 44/2010, $93 / 2012,89 / 2013$ ) and a number of legal acts in the field of higher education. 
Given that it is of a particular importance for the Republic of Serbia, this activity is directed towards increasing the number of residents with higher education, providing opportunities for individuals to have equal access to higher education, and to be able to educate themselves throughout their lives. Defined objectives and principles of higher education in Serbia are related to equality and accessibility, transparency and openness, lifelong learning, harmonisation with the European system of higher education, and improvement of academic mobility programmes. Moreover, it should encourage students' participation in governance and decision-making, raise the bar on respect for human rights, and focus on democratic and humanist values, quality and efficiency of education. It can be concluded that these above-mentioned goals are compatible with the principles of sustainable development.

In 2012, the Government of the Republic of Serbia adopted the Strategy for the Development of Education in Serbia 2020 (Official Gazette of the Republic of Serbia, no. 107/2012). The strategy deals with determining the purpose, goals, directions, instruments and mechanisms for the development of the education system in the Republic of Serbia until 2020. The strategy's mission is to design an education system that should provide each individual, the society, and the whole state with the basic life's foundation for development that is based on knowledge. It is the first comprehensive document that integrates educational policies of various segments of the education system from pre-school to lifelong learning with a special emphasis on higher education. The issues of education for sustainable development are not particularly emphasised and discussed within this strategy, but the solutions proposed are fully compatible with the principles of sustainable development.

The National Sustainable Development Strategy of the Republic of Serbia for the period 2008-2017 is the only cross-sectoral policy document that explicitly indicates the Education for Sustainable Development resolution as one of its priorities, in the chapter entitled "The Serbian Economy - Knowledge-based Sustainability". However, the ESD concept, defined by the Vilnius framework, is not entirely congruent with the treatment of education in the NSDS. Although most key ESD priorities are present, the focus is more on contributing to sustainable economic development, through improving education system quality and efficiency, coverage, and coordination with the labour market.

The NSDS promotes specific objectives as follows:

- Provide more favourable general conditions for economic-financial, institutional and technical support to the process of reforming the system of education and education for sustainable development;

- Promote the concept and practice of sustainable development and the system of sustainable education through formal and informal ways of learning;

- Provide adequate training on sustainable development for teachers at all levels of education;

- Work systematically to develop research in the field of sustainable development and education for sustainable development;

- In implementing the reform of education, continually promote cooperation at the national, regional and international levels (NSDS, 2008).

The NSDS as an "umbrella" strategy promotes professional development for university educators as a specific objective, but without any operationalisation. The NSDS Action Plan (2008) assigned concrete activities, some of them promoting ESD through professional 
development of teachers (not exclusively in higher education) and improvement of skills and capacities. Unfortunately, this strategy has rarely been implemented through concrete policies and it is considered "dead" today.

Higher education reform according the Bologna process is of particular importance if we want to understand the role of higher education institutions for sustainable development (Copernicus Campus, 2012). Serbia signed the Bologna declaration in Berlin in 2003. The University of Belgrade, the University of Niš, and the University of Kragujevac endorsed the COPERNICUS Charter (The University Charter for Sustainable Development, 1994). Therefore, three Serbian universities are part of the COPERNICUS context, dedicated to promotion and implementation of the principles of sustainable development in their curricula and to highlighting the role of universities, at the local and regional level, in their responsible creation of a balance between economic, ecological, and cultural aspects of society (The Conference of European Ministers Responsible for Higher Education, Bergen, 2005; COPERNICUS-CAMPUS, 2005).

In recent years, the Bologna Process has conditioned a revision of study programmes and definition of a new approach to higher education in the Republic of Serbia. All the Serbian universities have adopted strategic plans and initiated a course of action towards advancing the cause of sustainability at universities: mobility, resource optimisation, curriculum changes, networking, dissemination of knowledge, partnerships, awareness raising on environmental issues, etc. (Pavlović, 2011), but ESD has not been integrated into the quality assurance and formal accreditation of higher education institutions so far. In this regard, there is still a lack of strong motivation for changes, there is little support for the social and political elite, there are no significant system programmes of raising awareness on environmental issues and problems, there are insufficiently developed programmes of lifelong education and sustainability research and others (Milutinović and Nikolić, 2014).

One of the national priorities for achieving sustainable development in Serbia is related to the protection and enhancement of the environment and rational use of natural resources. In this regard, a series of laws and subordinate regulations in the field of environmental protection in accordance with EU directives are adopted, but there is a lot to be done to improve the situation in this area. In addition to the need to improve the implementation of legal regulations, it is necessary to improve public participation, public debate in the decision-making process, develop inter-institutional cooperation, and raise the level of knowledge and awareness of the problems and the need for protecting the environment (Serbia 2013 Progress Report, European Commission, 2013). Objectives, rules, and priorities related to environmental protection and the need for and importance of reform of education and educational needs in this field are pointed out in the fifth part of the NSDS (NSDS, 2008). However, the implementation of the reforms is still slow, realistic action plans are lacking, and comprehensive approaches to harmonise education with labour market needs and sustainable development have not been applied (Serbia 2013 Progress Report, European Commission, 2013; Pavlović, 2011).

\subsection{Programmes in environmental education}

One of the requirements of the Bologna Process is the accreditation of higher education institutions and their study programmes. According to the latest list of the Commission for Accreditation and Quality Assessment (CAQA) of the Ministry for Education, Science and Technological Development of Serbia, in early 2014, there are 79 public faculties, 18 private faculties, and 80 colleges of applied sciences that have accredited their courses (Guide for Students, 2014). According to data from the school year 2013/2014, about $80 \%$ of the students attend state universities and colleges, while nearly $20 \%$ of the total student population enrols in private universities (see Table 1). 
Table 1: Numbers of students attending public and private universities

Source: Statistical Office of the Republic of Serbia, Belgrade, 2014

\begin{tabular}{|c|c|c|c|}
\hline \multicolumn{2}{|c|}{ PUBLIC UNI VERSITIES } & \multicolumn{2}{|c|}{ PRI VATE UNI VERSI TI ES } \\
\hline University & $\begin{array}{l}\text { Number of } \\
\text { students }\end{array}$ & University & $\begin{array}{l}\text { Number of } \\
\text { students }\end{array}$ \\
\hline University of Belgrade & 73,480 & Megatrend & 7177 \\
\hline University of Arts in Belgrade & 2235 & European University & 2167 \\
\hline University of Novi Sad & 35,331 & Metropoliten & 745 \\
\hline University of Kragujevac & 13,743 & Singidunum & 8928 \\
\hline University of Niš & 18,973 & Edukons & 2717 \\
\hline State University of Novi Pazar & 2403 & Union & 2596 \\
\hline Colleges of Applied Sciences & 41,190 & Alfa & 1359 \\
\hline \multirow[t]{4}{*}{$\begin{array}{l}\text { University of Defence/ Military } \\
\text { Academy }\end{array}$} & 2083 & $\begin{array}{l}\text { International University of } \\
\text { Novi Pazar }\end{array}$ & 2051 \\
\hline & & Business Academy in Novi Sad & 4781 \\
\hline & & Colleges of Applied Sciences & 5979 \\
\hline & & Faculties outside universities & 593 \\
\hline $\begin{array}{l}\text { Number of students enrolled } \\
\text { in public universities }\end{array}$ & 189,438 & $\begin{array}{l}\text { Number of students enrolled in } \\
\text { private universities }\end{array}$ & 39,093 \\
\hline \multicolumn{3}{|l|}{ In total } & 228,531 \\
\hline
\end{tabular}

\subsubsection{Study programmes for professionals in the field of environmental protection}

The results of our Internet and desktop research indicate that a number of universities and colleges of applied sciences have accredited their study programmes, with the aim of providing professional education for work in the environmental field. It can be noticed that for the past ten years there has been an increase in the numbers of higher education institutions that offer programmes for educating professionals/specialists for environmental protection (Table 2).

Analysing the List of professional, academic and scientific titles with the indication of occupation in respective degrees approved by the National Council for Higher Education in 2007 (Official Gazette of the Republic of Serbia, no. 76/05, no. 81/2010), the following academic and professional titles in the field of environmental protection are identified: 
1. ecologist, graduated ecologist-master, graduated ecologist-specialist, doctoralenvironmental sciences; professional career ecologist, professional career ecologistspecialist;

2. environmental analyst, graduated environmental analyst-master, graduated environmental analyst-specialist, doctoral-environmental sciences; professional career environmental analyst, professional career environmental analyst-specialist;

3. environmental engineer, graduated environmental engineer-master, graduated environmental engineer-specialist, doctoral-environmental sciences; professional environmental engineer, professional environmental engineer-specialist.

Table 2: Environmental higher education in the Republic of Serbia

\begin{tabular}{|c|c|c|c|c|c|c|c|c|c|}
\hline \multirow[b]{2}{*}{ Higher Education } & \multicolumn{3}{|c|}{$\begin{array}{c}\text { Number of } \\
\text { accredited } \\
\text { environmental } \\
\text { curricula }\end{array}$} & \multicolumn{3}{|c|}{$\begin{array}{c}\text { Number of } \\
\text { accredited } \\
\text { environmental } \\
\text { curricula }\end{array}$} & \multicolumn{3}{|c|}{$\begin{array}{c}\text { Number of } \\
\text { accredited } \\
\text { environmental } \\
\text { curricula }\end{array}$} \\
\hline & & 00 & & ( $\mathrm{M}$ & $\begin{array}{l}01 \\
\text { ov }\end{array}$ & & & $\begin{array}{l}2014 \\
\text { rigin }\end{array}$ & \\
\hline Profile & B & $\mathbf{M}$ & D & B & $\mathbf{M}$ & D & B & $\mathbf{M}$ & D \\
\hline $\begin{array}{l}\text { Environmental } \\
\text { engineer }\end{array}$ & 2 & 1 & 1 & 5 & 5 & 2 & 9 & 7 & 4 \\
\hline $\begin{array}{l}\text { Environmental } \\
\text { analyst }\end{array}$ & 0 & 0 & 0 & 4 & 4 & 0 & 4 & 6 & 0 \\
\hline Ecologist & 1 & 1 & 0 & 1 & 3 & 0 & 4 & 5 & 4 \\
\hline $\begin{array}{l}\text { Environmental } \\
\text { chemist }\end{array}$ & 0 & 0 & 0 & 2 & 0 & 0 & 2 & 0 & 0 \\
\hline Agro-ecologist & 0 & 0 & 0 & 1 & 0 & 0 & 1 & 0 & 0 \\
\hline $\begin{array}{l}\text { Environmental } \\
\text { geographer }\end{array}$ & 0 & 0 & 0 & 1 & 0 & 0 & 1 & 0 & 0 \\
\hline $\begin{array}{l}\text { Environmental } \\
\text { biologist }\end{array}$ & 0 & 0 & 0 & 1 & 0 & 0 & 1 & 0 & 0 \\
\hline Vocational studies & & & & & & & $B$ & Spec & \\
\hline $\begin{array}{l}\text { Environmental } \\
\text { engineer }\end{array}$ & 2 & & & & & & 14 & 3 & \\
\hline
\end{tabular}

Note: B - Bachelor study programme; M - Master study programme; D - Doctoral study programme

However, the list of titles issued by the National Council for Higher Education also specifies titles that graduates acquire after interdisciplinary, multidisciplinary, transdisciplinary (IMT) and two-course study programmes (graduated ecologist of environmental law, graduated ecologist of environmental law-master, graduated engineer of energy 
efficiency in buildings, graduated engineer of energy efficiency in buildings-master). The future employment of these professions involves solving a series of system problems or adopting a number of its solutions.

\subsubsection{Environmental content in the study programmes of faculties that do not educate students/ professionals in the field of environmental protection}

Our desktop research results for study programmes that are not designed for training specialists in the field of environmental protection show that the environmental protection content (as separate subjects/autonomously or as part of other subjects/integrative) are mostly present at faculties that have accredited their study programmes in the field of technical and technological sciences (most number within the engineering departments), and then at faculties that have accredited their study programmes in the field of natural sciences and mathematics, but still not adequately represented at economic and humanistic departments (Figure 1).

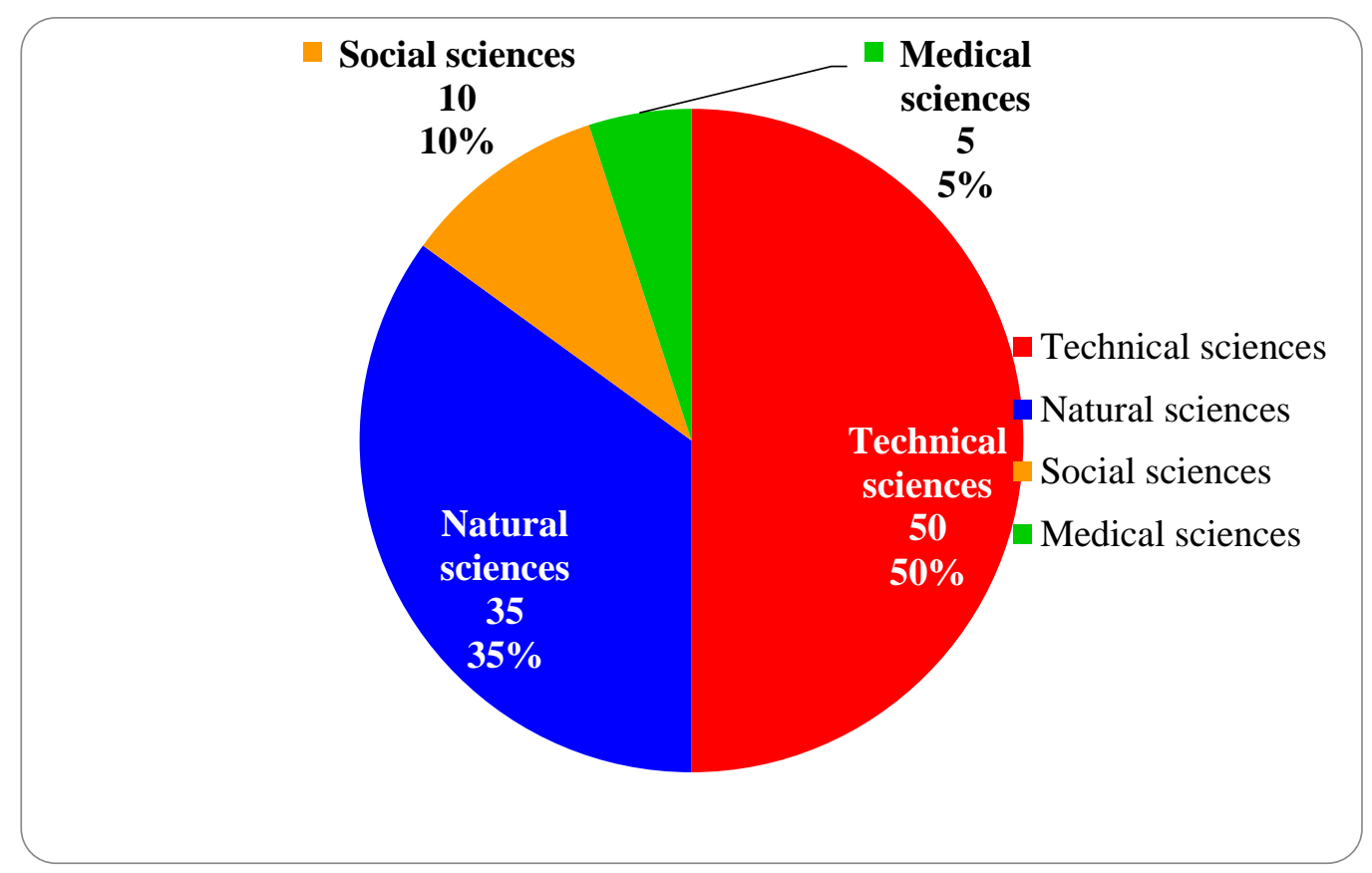

Figure 1: Representation of environmental protection contents at faculties that have accredited their programmes within different scientific fields

There is a tendency to ecologise, or green, the universities, namely, to introduce disciplines referring to environmental protection and sustainable development and other diverse socio-humanistic sciences at a number of technical faculties. The main problem in the curricula is not the number of courses, but the general orientation towards corrective and preventive measures and methodologies within the course contents, rather than towards values, change management and substantial sustainable development principles, which are often lacking (Milutinović and Nikolić, 2014). 
The path towards greening higher education is not easy. The problems are numerous and demanding. The most common problems are related to insufficient support of the relevant educational authorities in general greening of universities. Lack of will and desire for change and even resistance to change are present, too. Lack of interdisciplinary approaches in the design of programmes, absence of finance and investment in education, lack of environmental education in current curriculum outcomes, underdeveloped ecopedagogical competencies of teaching staff are all problems that Serbian higher education is facing today (Milutinović and Nikolić, 2014; Kovač-Cerović, 2006; Pavlović, 2011; Andevski, Florić, 2002).

From the didactic and methodological point of view, one could say that greening is a process of introducing ecological principles and approaches in different educational disciplines in the function of a complex comprehension and exploration of the issues of environmental protection and sustainable development (Kozlova and Glazačev, 1998; Logunov et al., 1998). In a broader theoretical context, this approach is reasonable and acceptable, but the results of the practice point to a number of difficulties and problems, mainly related to teachers' competences in this area (Andevski and Florić, 2002; Nikolić, 2003; Kundačina and Andevski, 2004).

The main problem is that the teachers of certain courses are required to possess competencies that include:

- broader professional and methodical knowledge of environmental issues and sustainable development (more than they have already acquired before), and

- expert level of programming and teaching the educational content (especially when connecting some educational materials to the contents of environmental protection and sustainable development (ibid.).

Considering the above-mentioned, the material connected to environmental protection and sustainable development is neglected and lost in the course of teaching, and the educational effects, in this respect, are minimal (ibid.).

For this reason (though perhaps less didactically justified), single-subject teaching, in the relevant field of environmental protection and its wider cross-curricular connections in the framework of an educational plan and programme, are often implemented. For such a didactic approach, there are two important arguments (Nikolić, 2012):

- the programme content of environmental protection is organised according to didactic logical order and sequence of the respective profession, business or occupation at a scope and depth that is suitable for the type and level of education, and

- a lecturer of an appropriate profile, with an appropriate expertise and didacticmethodical preparation for successful course delivery, is provided.

Our desktop research of the study programmes of higher education institutions in the Republic of Serbia indicates that a number of faculties and colleges have adopted an autonomous approach and implemented autonomous single subjects with contents that are related to environmental protection within their study programmes. This in particular refers to study programmes that are not intended for professional education of specialists in the field of environmental protection. Our comparison with the results of a similar study, which was conducted by one of the authors of this paper in 2003 (Nikolić, 2003), points to a significant progress in this area. In comparison with the situation ten years ago, today's 
situation is much better, but still an unsatisfactory representation of contents related to environmental protection and sustainable development at the faculties of social sciences and humanities can be found.

\subsubsection{Greening of the English syllabus/ English for sustainability}

Given the importance of the English language in response to the challenges of globalisation, the flow of knowledge, international scientific research, mobility, knowledge economy, and green business, special attention has been paid to the greening of the English syllabus. Castells (2000) notes that the English language is a necessary tool for today's society if its members want to participate fully in the global world community and advance politically, economically and socially. Trudell (2009) also points out that the issue of language ability and communication skills in truly sustainable development deserves careful attention. The development of language and communication skills is essential in overcoming the barriers of students', teachers', and researchers' mobility, global connection, the transmission of new knowledge, learning from each other, the development of transnational understanding, cultural sensitivity and cooperation. When learning incorporates the global dimension, learners develop the skills, knowledge and confidence to make responsible choices about lifestyles that contribute positively to a sustainable society (Copernicus, 2012). The methodology, curricula, textbooks and studies of the English language must be future-oriented, engaging learners in the kinds of thinking that lead to knowledge, skills and dispositions that support environmental protection and sustainable development.

Implementing environmental contents and ideas of sustainable development in existing studies of the English language is clearly one way to incorporate them into the learning experience. This part of the paper summarises a short review of the results of an empirical study of representation of ecological ideas and content in the English syllabus, as the most common course in the study programmes at Serbian faculties. Reviewing the environmental content in English language teaching, it is shown that environmental issues and ideas are present in programmes of those universities that prepare future professionals for work in the field of environmental protection.

This research included faculties that are part of the University of Niš and the University of Novi Sad. The University of Niš consists of 13 faculties, but at the time of making this study, only 4 faculties/ 5 study programmes had published their English syllabuses on the faculties' official websites; whereas only 4 out of the 14 faculties that are part of the University of Novi Sad had published their English syllabuses officially.

The research shows that the faculties that educate students in the field of environmental protection, i.e., the Biology and Ecology, Architecture and Civil Engineering, Hydraulic, Water Resources and Environmental Engineering programmes, post their programmes online. The focus is on language for specific purposes, and the required literature is directly related to the development of knowledge within specific disciplines.

The lectures are combined with interactive communicative exercises on a weekly basis (mostly 4-5 hours). These study programmes also include discussions, colloquia, and seminars. It can be concluded that the programmes provide language learning with an emphasis on technical terminology, translating technical texts, as well as active command of the language. These programmes enable the acquisition of new, as well as broadening of existing knowledge, as well as training for further education and self-education with the help of dictionaries and technical literature, which develops autonomy in learning. Students are required to be able to communicate on themes from everyday life and professional teaching topics using all language skills. 
For the implementation of sustainability issues in English language syllabuses, it is necessary to ensure that educators understand the concept of sustainability and are familiar with its principles. When they understand the concept of sustainability, educators from each discipline can examine the existing curriculum and school activities to contribute to ESD. Furthermore, educators can identify potential areas of the existing curriculum, in which examples that illustrate sustainability or additional knowledge, issues, perspectives, skills and values related to sustainability, can be inserted.

\section{Discussion}

Higher education plays an important role on the path towards sustainable development. In this regard, it is a major challenge in the higher education system to take advantage of all the opportunities and possibilities of research and teaching at the universities, and meet the requirements of sustainable development in the future. Changes in the higher education (greening the curriculum) are the result of hard decisions and a strong will to change the way in which future professionals think and work. In the core of this process, there are three important principles that single out: transdisciplinarity, universities' collaboration and "educating the educators" (Lozano et al., 2013). Thus placed postulates, although reduced to only three basic items, indicate the origin of the problem during the "curriculum greening", which may be caused by general and individual factors, such as organisational and financial power of higher education institutions, or level of motivation and competence of subjects involved in the teaching process.

In Serbia, the biggest obstacles to greening higher education are the traditional resistance to change at higher education institutions, and insufficient support of central authorities and government when it comes to environmental concerns and fostering sustainable practices. Moreover, universities are not legally forced to develop environmental planning and reporting, and environmental training and lifelong education is not a common practice at Serbian universities. There is a lack of interdisciplinary and multidisciplinary approaches to education, low level of integration at public universities, poor cooperation and connection between higher education and the economy sectors and others (Milutinović and Nikolić, 2014; Kovač-Cerović, 2006). Learning/ teaching towards sustainability at universities is not only a declaration of good goals and requirements in terms of environmental protection, but also the beginning of a long process that involves changes in epistemological, philosophical, political, and social conceptions of all university members.

Starting from the UNECE Strategy, which has been adopted in Serbia, it is clear education in the field of environmental protection should be developed and complemented with other areas of education in order to obtain an integrative approach that would lead to true education for sustainable development. Key themes of sustainable development, inter alia, include many issues, such as poverty reduction, civil society, peace, ethics, and responsibility in local and global contexts, democracy and governance, justice, security, human rights, health, gender equality, cultural diversity, rural and urban development, industry, shared responsibility and others (Nikolić, 2011).

Beside curricular changes, it is necessary to conduct didactic-methodical changes in the system of higher education (Nikolić, 2012). Instead of education that simply includes reproduction of knowledge, a new paradigm is oriented towards a creative mastery of the knowledge that, in addition to 'mastering the world', includes the establishment of the ecological relationship to the world (Tilbury, 2004; Dlouhá and Dlouhý, 2014). The educational process should be focused on active pedagogical relations of cooperation and dialogue oriented towards a comprehensive, integrative and complex approach to determine 
the content, rather than a passive object-subject relationship (teacher-student, teacherlistener) in teaching. Also, instead of single-subject teaching in didactic terms, instead of the monopoly of educational institutions, this concept prefers variety of educational programmes (extra-curricular programmes which are empowerment activities that give students deeper experience and commitment to environmental sustainability outcomes (Ceres Community Network, 2004; Streamwatch, 2002).

Moreover, active learning methods and active-oriented teaching (to activate students to participate in education and to participate in environmental protection) and multimedia education technologies are preferred, which, in fact, ultimately should contribute to liberalisation (freedom of choice to have an individual educational path) and a democratisation of the system. These requirements are related to the provision, publication, availability and use of information through electronic media as the basis for democratic decision-making in the area of the environment; development of interdisciplinary dialogue with stakeholders outside the academic sphere, the development of communication sandwiched between teachers and students, the development of e-learning and others (Butcher, 2011; Glennie et al., 2012).

In this respect, the educational system is still lagging behind in practice. Some reasons for this situation can be found in the teachers' underdeveloped competencies in the field of education for environmental protection and education for sustainable development. Since teaching at universities in Serbia is predominantly performed ex cathedra, whereas education for sustainable development demands mutual learning, participation, experiential learning, and methods of active learning (Dlouhá and Dlouhý, 2014), it is necessary, beside developing professional competencies, to pay special attention to the development of didactic and methodical competences for the realisation of successful educational work in this field. However, such training programmes to educate educators in sustainable development do not exist in the Republic of Serbia. The programme ${ }^{1}$ of informal education of teachers entitled "Environmental education on the way to a sustainable society Ecopedagogical competencies as a basis for sustainable development", whose author is also one of authors of this paper, should be mentioned. Unfortunately, the programme has not been implemented more widely.

We assume that the main reason for this lies in the lack of theoretical foundation and insufficient elaboration of this issue. However, given the complexity of the environmental concerns and problems, especially in cases where their solutions require significantly greater operability and decisive action, such a delay cannot be justified.

\section{Conclusion}

In an effort to join the society of European countries (EU), Serbia has committed itself towards a sustainable path. The concept of sustainable development in Serbia is seen as an opportunity and a chance to create a new consciousness regarding sustainability in the field of environmental protection, health, energy, natural capital, education, economics, etc.; in

\footnotetext{
${ }^{1}$ Andevski, M., Kundačina, M., Đorđević - Nikolić, V., Klemenović, J. “Environmental education on the way to a sustainable society - Ecopedagogical competencies as a basis for sustainable development". The programme was accredited by the Serbian Ministry of Education and Sports, Programme catalogue for the school year 2003/2004; Ministry of Education and Sports of the Republic of Serbia, Belgrade, 2003.
} 
general, to give opportunities for a higher quality of life in the future. Within the context of the legal and policy framework, Serbia has adopted a National Strategy of Sustainable Development (NSDS, 2011) and an Action Plan for its implementation, and therefore has taken a number of commitments to reform the economy and society as a whole. However, the economic crisis and internal structural problems have made Serbia to face a series of challenges to sustainable development: poverty, uneven regional development, and problems of environmental protection, demographic problems, insufficient investment in education, science and research, and others.

Evaluation of the higher education content of the Republic of Serbia during the Decade of Education for Sustainable Development has shown that most of the activities for the implementation of education for sustainable development were implemented in terms of education for environmental protection. It is an indisputable progress that has been made in respect of professional education of future experts on environmental protection, and also in respect of the introduction of special courses related to environmental protection in the curricula of different universities. However, broader greening of higher education is still limited. Universities in Serbia are not legally forced to develop interdisciplinary and multidisciplinary environmental programmes that would enable a tighter connection between the concept of environmental protection and other issues and problems of sustainable development. In our opinion, a "green curriculum" should be introduced following a bottomup approach. However, some pressure from the macro level is needed, i.e., it should be the general policy of central authorities.

In fact, it can be concluded that there is an absence of a holistic approach that would integrate all the relevant contents of environmental protection and sustainable development in a way that they form an inseparable whole, and bring them into direct contact with the interests of the target groups/students. The reasons for this may be the complexity of the concept of sustainable development, but also the fact that the creators of the educational system reforms have no clear strategy when it comes to customising this concept to a particular programme of study, scientific discipline, and education level.

As a typical peripheral developing country regarding higher education, the Republic of Serbia is extremely interested both in sharing its higher education sustainable development (HESD) experience and in learning about European best HESD practices through participation in UE4SD. The University of Niš, the Serbian HESD hub, participates in and actively contributes to the discussions generated at UE4SD regional and annual meetings, seminars and conferences, assists in the development of an online platform of resources as well as gets familiarised with and reviews the online HESD tool. Moreover, the University of Niš will contribute to the dissemination and exploitation of the project outputs, outcomes and future network activities.

\section{Acknowledgements}

Research reported here is part of the project titled "University Educators for Sustainable Development", Lifelong Learning Programme. ERASMUS Programme: Erasmus Academic Networks. This work is supported by the Ministry of Education, Science and Technological Development of the Republic of Serbia under Grant III 42006 and Grant III 44006. 


\section{References}

- Andevski, M., Kundačina, M., Đorđević - Nikolić, V., Klemenović, J., (2003).

Ekološko obrazovanje na putu u održivo društvo - Ekopedagoške kompetencije kao osnova održivog razvoja, Program akreditovan kod Ministarstva za prosvetu i sport Republike Srbije, Katalog programa za školsku 2003/2004. Beograd: Ministarstvo za prosvetu i sport Republike Srbije.

- Higher Education Act, "Official Gazette of the Republic of Serbia", no. 76/2005, 100/2007 - authentic interpretation, 97/2008, 44/2010, 93/2012, and 89/2013. .

- Гуманизация и екологизация в образовании: тенденции и перспективы, Экологиечская культура и образование: опьит России и Югославии (1998). Moscow: Медждународная Академия Наук.

- List of professional, academic and scientific titles with the indication of occupation in respective degrees, Official Gazette of the Republic of Serbia, no. 76/05 and no. $81 / 2010$.

- Логунов, А.А., Соколов, В.Е., Шилов, И.А., (1998). Современные проблем ы Экологического образования, Вестник АН СССР, ХII/1998.

- Marcinkowski, T. J. (2009). Contemporary Challenges and Oppurtunities in Environmental Education: Where are We Headed and What Deserves Our Attention. J ournal of Environmental Education, 41(1), 34-54. Retrieved from http://www.tandfonline.com/doi/abs/10.1080/00958960903210015http://dx.doi.o $\mathrm{rg} / 10.1080 / 00958960903210015$

- Nikolić, V. (2003). Education and Environmental Protection. Beograd: Zadužbina Andrejević.

- Nikolić, V. (2012). Theory and Organization of Safety Education. Niš, Serbia: Faculty of Occupational Safety, University of Niš.

- Nikolić, V. (2011). Education and sustainable development within monograph "Signposts Towards Sustainable Development", under auspices of The Office for European Integrations of the Deputy Prime Minister. Belgrade: Ministry of Science and Technology of the Republic of Serbia.

- National Sustainable Development Strategy (2008-2017) (2008).

- Potter, G. (2009). Environmental education for the 21st century: Where do we go now. The Journal of Environmental Education, 41(1), 22-33.

http://dx.doi.org/10.1080/00958960903209975

- The social dimension of higher education in Serbia, Studija zatečenog stanja, EQUI-ED, 2012.The Strategy of Education Development to 2020, Official Gazette of the Republic of Serbia, no. 107/2012.

- Tilbury, D. Environmental education for sustainability: a force for change in higher education, In Blaze Corcoran, P., and Wals, A.E.J. (Ed.), Higher Education and the Challenge of Sustainability (pp. 97-112). Dordrecht: Kluwer Academic Publishers. 
- Universities, (1986). Universities and environmental education, The development of higher education. Paris: UNESCO and the International Association of Universities.

- Commission for Accreditation and Quality Assurance, (2014). Guide for Students. http:

www. kapk. org/index. php? option=com_content\&amp; task=view\&amp; id=42\&amp; Itemid=52\&amp; lang=en . Retrieved from http://www.kapk.org/index.php?option=com_content\&task=view\&id=42\&ltemid= $\underline{52 \& l a n g=e n}$

PhD Vesna Nikolić, Faculty of Occupational Safety, University of Niš

PhD Slobodan Milutinović, Faculty of Occupational Safety, University of Niš

Jelena Ranitović, Faculty of Occupational Safety, University of Niš 